\title{
MANAGEMENT OF CITATION VERIFICATION REQUESTS FOR MULTIPLE PROJECTS AT SANDIA NATIONAL LABORATORIES*
}

\author{
Carol S. Crawford \\ Technical Library, Information Research Department \\ Sandia National Laboratories \\ Albuquerque, NM 87185
}

\begin{abstract}
Sandia National Laboratories' (SNL) Technical Library is now responsible for providing citation verification management support for all references cited in technical reports issued by the Nuclear Waste Management (NWM) Program. This paper describes how this process is managed for the Yucca Mountain Site Characterization (YMP), Waste Isolation Pilot Plant (WIPP), Idaho National Engineering Laboratory (INEL), and Greater Confinement Disposal (GCD) projects. Since technical reports are the main product of these projects, emphasis is placed on meeting the constantly evolving needs of these customers in a timely and costeffective manner.
\end{abstract}

\section{Background}

Since late 1989, citation verification management support of "report references" has been provided to SNL/Yucca Mountain Site Characterization Project (YMP) by a technical librarian. In 1989, YMP had the records management requirement (now superseded AP$1.18 \mathrm{Q}$ ), requiring that copies of all report references be filed in the Central Records Facility (CRF) in Las Vegas. Accession numbers were also assigned to each report reference and this records information was entered into Sandia's citation tracking database and the Records Information System (RIS). SNL/YMP authors were also required to print this accession number following the citation of the corresponding report reference. YMP project participants were required to supply copies of all report references that did not already have accession numbers recorded in the YMP RIS.

*This work was supported by the United States Department of Energy under contract DEAC04-94AL85000. 
In March 1992, the SNL/Waste Isolation Pilot Plant (WIPP) project retained the services of a technical librarian to verify that all citations listed in project technical reports were publicly available. If a citation was found to be unverifiable, SNL/WIPP authors were required to provide a copy of the document, which was then filed in the Sandia WIPP Central Files (SWCF). This technical librarian also verified that citations found in WIPP reference lists were formatted to the format set forth in the Concise Format Guide (Garber et al., 1992), which had been distributed earlier that year. The decision was made to retain a technical librarian, to assist in the implementation of this new requirement on the citation of publicly available materials and to assist authors in implementing the format spelled out in the Concise Format Guide. Also, one of the technical librarians who had worked with YMP report references was available for assignment to the WIPP project.

In January 1995, through its affiliated library contract, SNL's Technical Library contracted to provide citation verification support to that laboratories' Nuclear Waste Management (NWM) Program, which is responsible for the administration of SNL's involvement in various nuclear waste management projects. A technical information specialist (TIS) is assigned to that task on a full-time basis, with backup support from another TIS. Most of this support is provided to the YMP and WIPP projects, but support is also provided to the GCD and INEL projects. Citation verification support has also been provided to the Mixed Waste Landfill Integrated Demonstration (MWLID) and SNL's Accident Analysis/Consequence Assessment Department.

\section{Current Quality Assurance (QA) Requirements and Oversight}

SNL Quality Assurance Implementing Procedure (QAIP) 6-2 (SNL, 1995a) spells out the reference review requirements for the YMP project. Reference reviews are required for all SNL technical (SAND) reports and study plans.

SNL Quality Assurance Procedure (QAP) 6-2 (SNL, 1995b) is the procedure governing reference reviews for the WIPP project. Other WIPP technical documents (e.g., test plans, White Papers to the U.S. Department of Energy (DOE)) also undergo reference reviews.

Suffixed SAND reports (A-abstract, C-conference paper, J-journal article) are not required to undergo a reference review at the time they are submitted for the conference or journal, but they are put through a reference review if they are converted to full SAND reports. The SNL/WIPP project requires that conference papers and journal articles be reworked to meet project QA standards and published as full SAND reports.

Reference reviews are also subject to periodic audits by the DOE. The New Mexico Attorney General's office, the Environmental Protection Agency (EPA), and other oversight groups are also currently reviewing SNL's WIPP technical reports, including the bibliographic citations found in these reports. 


\section{Changing QA Requirements}

On August 10, 1994, SNL's WIPP QA Chief issued SNL WIPP QA Directive \#94-06, "Requirements for Citing Unpublished Documents." This directive required that copies of all unpublished documents cited in a draft SAND report be included with that draft when it was forwarded to the DOE for review and approval (R\&A). This directive was in response to the fact that recent reports (e.g., the Compliance Status Report) had included citations, by Sandia National Laboratories, of unpublished documents. Since the Compliance Status Report (U.S. DOE, 1994) was a DOE/WIPP document issued through Westinghouse Electric Corporation (WEC), it had not been subject to reference review by Sandia. Since DOE's Albuquerque office has assigned responsibility of these policy reviews to the Carlsbad Area Office (CAO) and the $\mathrm{CAO}$ has not been approving the citation of unpublished documents, such as internal contractor reports, these citations are usually deleted from WIPP SAND reports. If the author(s) will not remove these citations to unpublished documents, which a few have, their draft SAND reports are put on hold until the author gets CAO approval or the citation is removed. SNL management are still working with CAO on this issue.

On June 20,1995, the YMP issued Interim Change Notice (ICN) 4 to the project records management procedure (YAP-17.1Q, YMP, 1995), shifting responsibility for cited references from the Las Vegas Records Processing Center (RPC) to the Las Vegas Technical Information Center (LV TIC). The Las Vegas TIC was formerly named the Yucca Mountain Site Characterization Office (YMSCO) Research and Study Center. Since report references would be acquired and maintained by the Las Vegas TIC, the Las Vegas RPC immediately quit assigning accession numbers to report references and issuing preassigned accession numbers for technical reports going to the printer. Implementation of this ICN forced SNL to place a hold on the publication of YMP SAND reports until its internal procedure, "Preparing, Reviewing, Approving, and Issuing Technical Information Documents" (QAIP 6-2, SNL, 1995b) could be rewritten. The rewrite of this procedure was then delayed, because SNL had been told that the YMSCO would be issuing a guidance document to assist in the implementation of the ICN to YAP 17.1Q.

On July 6, 1995, Laura Tate of the YMSCO issued a memo via e-mail, "Guidance for Handling Cited References." This guidance called for the submittal of lists of ALL cited references to the Las Vegas TIC, stating that these lists should include such bibliographic information as reference title, author's name, publication date, publisher, revision or edition designator, and Library of Congress (LC), International Standard Book Number (ISBN), or other identifying number (for copyrighted or other public domain documents). The requirement that all cited materials be acquired and accessioned before a technical report could be published was also removed with implementation of this ICN.

SNL management then determined that YMP citation verification would continue to be covered under QAIP 6-2, since the TIC was not required to acquire cited materials before SAND reports were printed. SNL Technical Library staff continue to verify that materials cited 
in YMP SAND reports are publicly available and require that authors supply copies of materials that are unverifiable (e.g., papers from unindexed and/or unpublished proceedings volumes, preprints of journal articles accepted for publication, foreign dissertations). Citation errors are also identified and assistance is given to authors in using a single bibliographic format consistently throughout the reference list(s) of a specific technical report (the WIPP project is the only NWM project required to use a specific bibliographic format project-wide.) YMP authors are also required to resolve all citation issues, including providing copies of unverifiable references before obtaining publication approval for their technical report. Copies of complete reference lists, with copies of author-supplied unverifiable documents, will be forwarded to the Las Vegas TIC after the SAND report is printed. These materials are not sent to Las Vegas at an earlier stage in the process, since reference lists can change up to the time the report is printed.

\section{Citation Tracking Databases}

In late 1989, SNL/YMP references were tracked in a FoxPro database, REFS, which was maintained on an IBM personal computer. In 1991, that FoxPro database was converted into an Informix database on the AIMS (Administrative Information Management System). This FoxPro database was also merged with the SAND report processing database, which had been maintained on a Macintosh personal computer. Thus, YMP report reference and SAND report database records could be found in a single references/reports database on the administrative local area network (LAN).

When the decision was made to design a tracking database for WIPP citations, the AIMS system was not yet available to the WIPP project. The Nuclear Waste Management (NWM) Library was using an askSam database at that time, so the decision was made to use that software. WIPP management also did not want to pay for systems support to design a database. This database was designed by the technical librarian, who set up fields in a format similar to the bibliographic format set forth in the Concise Format Guide. Thus, it was possible to supply printouts of database records to report authors, which facilitated formatting of citations to the format spelled out in the Concise Format Guide.

When YMP and WIPP administrative support was assigned to one manager under the NWM Program, the decision was made to convert the WIPP askSam database to Informix and merge it with the AIMS references/reports database. Thus, database records from both NWM projects would be accessible from a single database on the administrative LAN and duplication of effort would be reduced (since a certain number of bibliographic citations are common to both projects.) Separate technical librarians supported the YMP and WIPP projects until January 1995, when the Technical Library contracted to provide these services as part of the affiliated library contract. Also, some manual cleanup of the AIMS database continues due to the merging of these two databases, keying errors, and differing entry of bibliographic information by various technical librarians and support staff. 


\section{Planning for the Future}

Until October 1, 1995, YMP citation verification has been funded by the records management function. With the changes in records QA requirements earlier this year, the citation verification function will be funded through SNL's technical budget elements beginning in FY 96. Citation verification for the other projects has been and will continue to be funded through the technical budgets, though commercial database costs were absorbed by records management/technical publications budgets for YMP and WIPP.

Since WIPP technical staff have always been responsible for financing citation verification support, it has been important to demonstrate that this service adds value to their technical reports and helps staff meet their QA requirements. In fact, that is how the support for other projects such as INEL came about. As staff from the NWM Program move on to other projects, they often want to retain the level of citation verification support they have received in the past.

When the technical staff are responsible for absorbing all these costs, it will be in their best interest to supply cleaner, less obscure citations. It will also be incumbent on the TIS to go to staff at an earlier stage in the citation verification process, rather than spending valuable professional time chasing obscure citations. It should then be possible to pursue citation verification work for other groups as the technical information specialist's time is utilized more cost-effectively and as backup continues to be provided by Sandia's Technical Library. This support from the Technical Library has proven to be valuable during busy crunches when technical staff from various programs are simultaneously attempting to meet milestones and other deadlines in very short periods of time.

\section{REFERENCES}

Garber, D.P., M.M. Gruebel, and E.N.S. Lorusso. 1992. "The Concise Format Guide for Waste Isolation Pilot Plant Program SAND Reports." Albuquerque, NM: Sandia National Laboratories. (Copy on file at the Nuclear Waste Management Information Center, Sandia National Laboratories, Albuquerque, NM.)

Sandia National Laboratories. 1995a. "Preparing, Reviewing, Approving, and Issuing Technical Information Documents." Sandia National Laboratories Yucca Mountain Site Characterization Project Quality Assurance Implementing Procedure (QAIP) QAIP 6-2. Albuquerque, NM: Sandia National Laboratories. (Revision dated August 18, 1995.) (Copy on file at the Nuclear Waste Management Information Center, Sandia National Laboratories, Albuquerque, NM.) 
Sandia National Laboratories. 1995b. "Preparing, Reviewing, and Approving Technical Information Documents." Sandia National Laboratories Waste Isolation Pilot Plant Quality Assurance Procedure (QAP) QAP 6-2. Albuquerque, NM: Sandia National Laboratories. (Revision dated July 31, 1995.) (Copy on file at the Nuclear Waste Management Information Center, Sandia National Laboratories, Albuquerque, NM.)

U.S. DOE (U.S. Department of Energy). 1994. Compliance Status

Report for the Waste Isolation Pilot Plant. DOE/WIPP 94-019, Revision 0. Carlsbad, NM: United States Department of Energy, Carlsbad Area Office.

YMP (Yucca Mountain Site Characterization Project). 1995. "Interim Change Notice 4 to Records Management Requirements and Responsibilities." ICN 4 to YAP-17.1Q. Las Vegas, NV: Yucca Mountain Site Characterization Project. (Copy on file at the Nuclear Waste Management Information Center, Sandia National Laboratories, Albuquerque, NM.)

\section{ACRONYMS}

$\begin{array}{ll}\text { AIMS } & \text { Administrative Information Management System } \\ \text { CAO } & \text { Carlsbad Area Office } \\ \text { CRF } & \text { Central Records Facility } \\ \text { DOE } & \text { U.S. Department of Energy } \\ \text { EPA } & \text { Environmental Protection Agency } \\ \text { FY } & \text { Fiscal Year } \\ \text { GCD } & \text { Greater Confinement Disposal } \\ \text { ICN } & \text { Interim Change Notice } \\ \text { INEL } & \text { Idaho National Engineering Laboratory } \\ \text { ISBN } & \text { International Standard Book Number } \\ \text { LAN } & \text { Local Area Network } \\ \text { LC } & \text { Library of Congress } \\ \text { LRC } & \text { Local Records Center } \\ \text { LV TIC } & \text { Las Vegas Technical Information Center } \\ \text { MWLID } & \text { Mixed Waste Landfill Integrated Demonstration } \\ \text { NWM } & \text { Nuclear Waste Management } \\ \text { QAIP } & \text { Quality Assurance Implementing Procedure } \\ \text { QAP } & \text { Quality Assurance Procedure } \\ \text { R\&A } & \text { Review and Approval } \\ \text { RIS } & \text { Records Information System } \\ \text { RPC } & \text { Records Processing Center } \\ \text { SNL } & \text { Sandia National Laboratories } \\ \text { SWCF } & \text { Sandia WIPP Central Files } \\ \text { TIC } & \text { Technical Information Center }\end{array}$


WEC Westinghouse Electric Corporation

\section{BIOSKETCH}

Carol S. Crawford is a Technical Information Specialist with Sandia National Laboratories and is responsible for managing citation verification support provided to the Nuclear Waste Management Program. She has provided citation verification support to Sandia since February 1990. She has also been employed as a Technical Librarian at Marathon Oil Company, Littleton, $\mathrm{CO}$ and as a cataloger and indexer at UMI (University Microfilms International), Ann Arbor, MI. Her M.S. in Library Science is from the University of Illinois, Urbana, IL.

\section{DISCLAIMER}

This report was prepared as an account of work sponsored by an agency of the United States Government. Neither the United States Government nor any agency thereof, nor any of their employees, makes any warranty, express or implied, or assumes any legal liability or responsibility for the accuracy, completeness, or usefulness of any information, apparatus, product, or process disclosed, or represents that its use would not infringe privately owned rights. Reference herein to any specific commercial product, process, or service by trade name, trademark, manufacturer, or otherwise does not necessarily constitute or imply its endorsement, recommendation, or favoring by the United States Government or any agency thereof. The views and opinions of authors expressed herein do not necessarily state or reflect those of the United States Government or any agency thereof. 


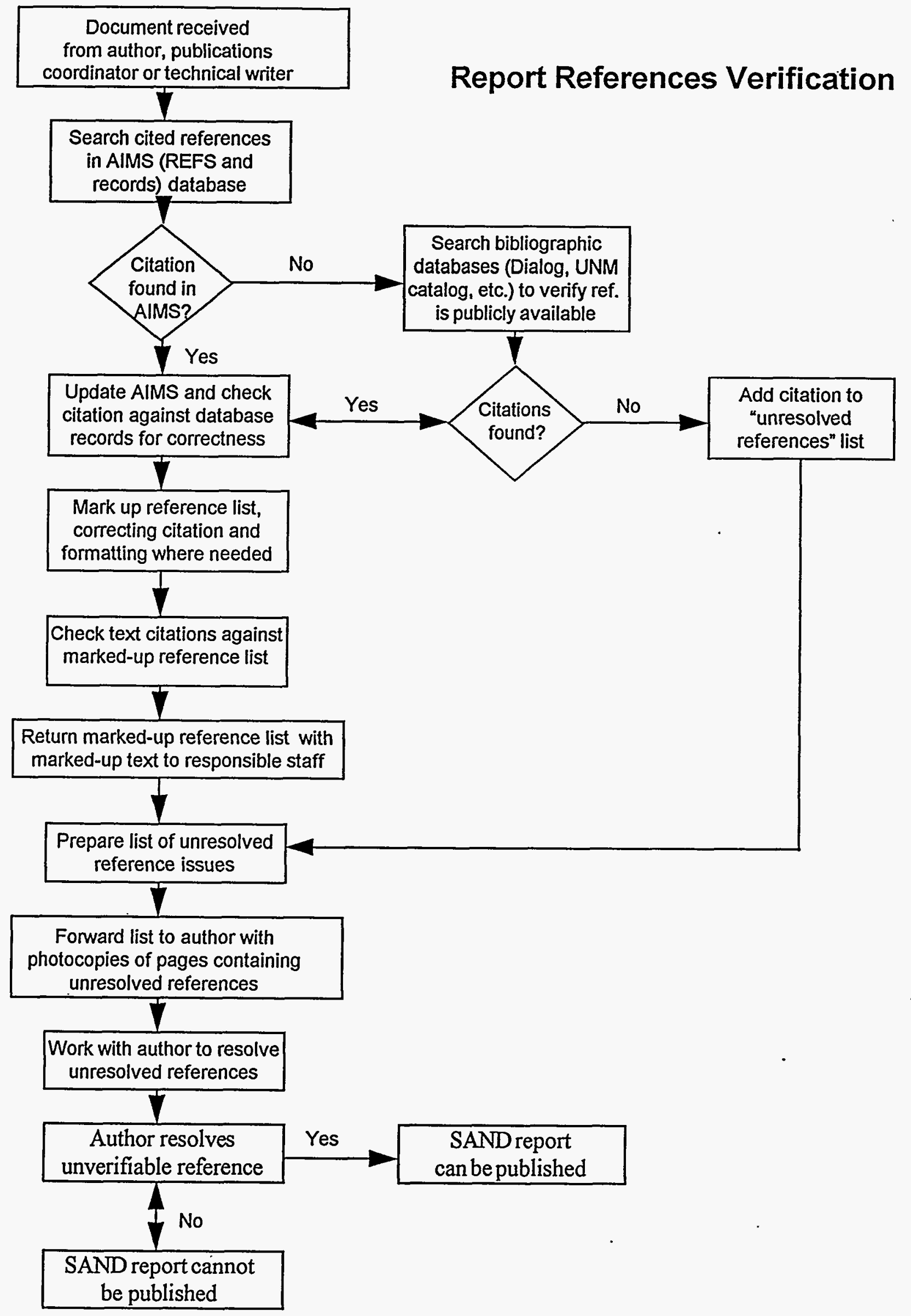

